\title{
Kompetencje ttumacza. \\ Tom dedykowany Profesor dr hab. Elżbiecie Tabakowskiej pod red. M. Piotrowskiej, A. Czesaka, A. Gomoli i S. Tyupy \\ Kraków 2012, ss. 420
}

Książka zatytułowana Kompetencje tłumacza to owoc współpracy dwóch katedr krakowskich uczelni: Katedry UNESCO do Badań nad Przekładem i Komunikacją Międzykulturową na Uniwersytecie Jagiellońskim i Katedry Dydaktyki Przekładu na Uniwersytecie Pedagogicznym. Publikację wydało Krakowskie Wydawnictwo TERTIUM. Zadedykowano ją pani Profesor Elżbiecie Tabakowskiej - niekwestionowanemu autorytetowi w dziedzinie przekładoznawstwa, zarówno zagranicznego, jak i rozwijanego w naszym kraju. Oddajmy głos redaktorce tomu, prof. Marii Piotrowskiej, która w wyjątkowy sposób podsumowała dotychczasowe dokonania Prof. Tabakowskiej:

„Właśnie ze względu na Jej osobę książka jest ważnym przyczynkiem w studiach o przekładzie; osobę, która na trwale wpisała się w krajobraz przekładowy - swoją teoretyczną koncepcją kognitywnej poetyki przekładu, swoją działalnością tłumaczeniową, między innymi jako tłumaczka Normana Daviesa, wieloletnią pracą naukową na Uniwersytecie Jagiellońskim i działalnością organizacyjno-dydaktyczną. Wizjonersko przewidując rosnącą rolę tłumacza we współczesnym świecie, wcześnie dostrzegała potrzebę kształcenia kompetencji przekładowej i stworzyła pierwszą w Polsce placówkę uniwersytecką zrzeszoną w sieci Katedr UNESCO edukującą tłumaczy i realizującą nowatorskie koncepcje tej edukacji w programie European Master's in Translation (...).

Bardzo trudno w zwięzłej formie opisać ogrom i wielowymiarowość działań naukowo-badawczo-dydaktycznych Profesor Elżbiety Tabakow- 
skiej. Rozległe horyzonty humanistyczne obejmujące lingwistykę w mariażu z literaturą, Jej niezwykła osobowość, dar wielkiego intelektu i mądrości emanowały i emanują na współpracowników i studentów. Własne doświadczenia językowe, posiadane kompetencje w kilku językach obcych oraz dokonania tłumaczeniowe - przekłady dzieł Daviesa, Mertona i innych, zapewniły jej niekwestionowaną pozycję w panteonie wielkich polskich tłumaczy" (s. 10-12).

Publikację otwierają Słowo wstępne autorstwa przywołanej wyżej M. Piotrowskiej, objaśniające motywy, jakie przyświecały twórcom tomu, i przybliżające sylwetkę Profesor E. Tabakowskiej, oraz Spis publikacji Profesor dr hab. Elżbiety Tabakowskiej. Kolejną część tworzą dwadzieścia trzy artykuły, stanowiące swoistą polifonię stanowisk na temat tak istotnego w przekładoznawstwie fenomenu, jakim są kompetencje tłumacza. Ten niezwykle wartościowy zbiór prac uznać można za jeden z najważniejszych współczesnych przeglądów polskiej myśli przekładoznawczej, który „z tak wielu punktów widzenia przynosi cenne wzbogacenie wiedzy na temat tłumaczenia $w$ jego różnych realizacjach i poszerza horyzonty poznania i rozumienia" (s. 9).

Część autorów opisała kompetencje tłumacza z punktu widzenia literaturoznawstwa. Jan Balbierz swoją pracę, zatytułowaną Gunnar Ekelöf: Pound, poświęcił intertekstualnym oraz interkulturowym kwestiom poezji, a także eseistyce modernisty Gunnara Ekelöfa i Ezry Pounda. Autor skoncentrował się głównie na koncepcji kultury, języka i przekładu u obu tych pisarzy.

Kolejny artykuł, autorstwa Aleksandra Gomoli, zawiera najistotniejsze uwagi natury praktycznej, które dotyczą translacji tekstów religijnych. Autor w niezwykle ciekawy i klarowny sposób zaprezentował rynek książki religijnej w Polsce oraz wymogi tłumaczenia tekstów religijnych, włącznie z sugestiami dotyczącymi warsztatu tłumacza.

Magda Heydel, w tekście zatytułowanym Import, szmugiel $i$ zdrada. Tłumacze w strefie konfliktu, zajęła się dość rzadko podejmowanym tematem $\mathrm{w}$ badaniach przekładoznawczych, a mianowicie tak zwaną strefą "pomiędzy", czyli, innymi słowy, strefą wzajemnego poznania i potencjalnego porozumienia, a zarazem obszarem różnicy i konfliktu. Przywołując historię Malinche, tłumaczki Hernana Corteza, Heydel dokonała próby ukazania tego jakże trudnego wymiaru pracy tłumacza i otworzyła pole do refleksji nad politycznymi i etycznymi uwarunkowaniami przekładu naznaczonego strefą wojny. 
Zajmujący artykuł Andrzeja Pawelca, pt. Skoro nie można mieć wszystkiego... O trzech przekładach wierszy Emily Dickinson (J 328), to refleksja nad kompetencjami tłumacza przekładającego poezję, a zarazem polemika z Małym, lecz maksymalistycznym manifestem translatologicznym S. Barańczaka. Autor artykułu starał się bowiem udowodnić, że kryterium ustalone przez wspomnianego poetę, a mianowicie: zachowanie dominanty semantycznej, jest zbyt sumaryczne. Dyskusja ta została wzbogacona o analizę trzech tłumaczeń wiersza J 328 Emily Dickonson: K. Iłłakowiczówny, S. Barańczaka oraz L. Marjańskiej.

Aspekty stylometrycznych „śladów tłumacza” (A. Pawelca, B. Pietrzyka, J. Rumińskiej i E. Tabakowskiej) to obszar badawczy Jana Rybickiego - autora kolejnego artykułu, zatytułowanego Tabakowska kontra Pawelec? Stylometria polskich przekładów twórczości Normana Daviesa. Autor dokonał wielowymiarowej analizy słownictwa niektórych przekładów Daviesa i sporządził listę słów-kluczy, które są typowe dla tłumaczy. Co ciekawe, Rybicki stwierdził, że niełatwo wskazać na tak zwany „sygnał tłumacza”, który mógłby w jakikolwiek sposób stłumić „sygnał autora".

Kwestie heterejęzyczności w powieści są tematem pracy Elżbiety Skibińskiej. Autorka - bazując na polskim przekładzie La Chartreuse de Parme Stendhala, francuskich przekładach powieści Konwickiego i dziełach S. Lema - dokonała analizy efektów heterojęzyczności w oryginalnych utworach i pokazała na przykładach sposoby, w jaki poradzili sobie z nią tłumacze.

W recenzowanej publikacji odnajdujemy także studium poświęcone językowi śląskiemu. Artur Czesak podkreślił wzmacniającą się pozycję tego języka, następującą dzięki przekładom dzieł z zakresu literatury światowej. Zwrócił też uwagę na niezwykle złożony charakter kompetencji tłumaczy tak zwanych „nowych” języków, zwłaszcza w obliczu braku instytucji regulujących taki przekład, krytyki przekładu, a nawet standardów ortograficznych czy gramatycznych.

Kompetencje tłumacza opisano $\mathrm{w}$ recenzowanym tomie również z perspektywy stricte pragmatycznej, mającej związek z kontekstem zawodowym osób zajmującej się przekładem. Poświęcony jest temu pierwszy, otwierający publikację artykuł, zatytułowany Kompetencja z punktu widzenia tłumacza. Jego autorką jest Joanna Albin. Tekst stanowi swoisty postulat uzupełnienia badań prowadzonych nad umiejętnościami zawodowymi tłumacza o uwarunkowania społeczne profesji oraz pojęcie po- 
czucia własnej skuteczności. Autorka poruszyła również rzadko podejmowany temat, jakim są czynniki afektywne.

Bardzo ciekawy artykuł Leszka Berezowskiego pt. Tłumacz angielskich dokumentów prawnych jako praktyczny znawca historii języka oryginału dotyczy kompetencji, jaką powinien posiadać tłumacz tekstów prawnych w zakresie znajomości niektórych elementów gramatyki historycznej języka angielskiego. Konieczność posiadania tych umiejętności autor zilustrował różnymi wersjami formuły tradycyjnie rozpoczynającej anglojęzyczne pełnomocnictwa.

W publikacji nie zabrakło prac związanych z przekładem audiowizualnym. Łukasz Bogucki i Mikołaj Deckert, w artykule zatytułowanym Kompetencja tłumaczeniowa a proces tworzenia interjęzykowych napisów filmowych, stwierdzili, że aby zdefiniować kompetencję tłumaczeniową w przekładzie audiowizualnym, należy określić zbiór różnych ograniczeń, czy też czynników, tłumaczeniowych, mających wpływ na proces decyzyjny tłumacza oraz na sposób, w jaki on pracuje. O kompetencjach tłumacza audiowizualnego napisała również Anna Jankowska, dzieląc je na twarde (ang. hard skills) i miękkie (ang. soft skills). Poddała je analizie, bazując na literaturze przedmiotu, wynikach badań ankietowych przeprowadzonych wśród tłumaczy należących do Stowarzyszenia Tłumaczy Audiowizualnych, a także na własnych doświadczeniach z zakresu tego rodzaju przekładu.

Agnieszka Chmiel postawiła przed sobą zadanie omówienia pamięci operacyjnej tłumaczy. W swojej pracy dokonała przeglądu badań nad tym zagadnieniem oraz przedstawiła eksperyment przeprowadzony z udziałem tłumaczy i osób bilingwalnych. W eksperymencie zastosowano Automated Reading Span - metodę polegającą na tym, że osoby badane zapamiętują kolejność liter, a jednocześnie dokonują oceny logiczności zdań. Wyniki badania wykazały, że tłumacze biorący udział $\mathrm{w}$ badaniu nie mieli lepszej pamięci operacyjnej niż osoby $\mathrm{z}$ grupy kontrolnej.

W artykule o intrygująco brzmiącym tytule Nie wszyscy równi wobec prawa, czyli dlaczego nie każdy prawnik może być tłumaczem Anna Nowakowska-Głuszak spróbowała odpowiedzieć na pytanie dotyczące kompetencji, jakimi powinien odznaczać się tłumacz tekstów prawnych. Autorka stwierdziła, że wiedza prawnicza to tylko jeden z czynników, które mogą warunkować dobre tłumaczenie, jednak nie jest ona najważniejsza praca tłumacza i prawnika bowiem, mimo pewnych wspólnych punktów 
na płaszczyźnie interpretacyjnej - to dwa zupełnie różne procesy, które wymagają stosowania całkowicie odmiennych metod.

Bardzo ciekawy temat poruszyła Bożena Wisłocka Breit. W artykule zatytułowanym Kiper kontra tłumacz: nierówna walka Goliata z Dawidem autorka przeanalizowała korpus not degustacyjnych (ocen wina), z których czterdzieści pięć stanowi bezpośrednie tłumaczenia tekstów występujących na stronach internetowych zagranicznych winiarzy. Skupiła się przy tym głównie na neologizmach i kalkach składniowych i semantycznych. Jak stwierdziła na początku pracy: „W procesie tłumaczenia, tym nierównym pojedynku, krytykowi winiarskiemu przypada pozornie korzystna rola Goliata, ale w języku docelowym to umiejętność i kompetencje tłumacza, metaforycznego Dawida, mają moc sprawić, że oryginalny tekst wywrze pożądane wrażenie na czytelniku, olśni go i uwiedzie, skłoni do kupna i skosztowania opisanego wina" (381). Jak widać, tłumacz musi także posiadać kompetencje copywriterskie, na które zwraca się uwagę dopiero od niedawna.

Kompetencje zawodowego tłumacza w kontekście kształcenia i przyszłego sukcesu zajęły Joannę Dybiec-Gajer, która postawiła sobie za cel dokonanie analizy koncepcji kompetencji tłumaczy z perspektywy profesjonalnej oraz omówienie modelu European Master's in Translation (EMT). Autorka zaprezentowała ponadto wyniki badań przeprowadzonych przy udziale tłumaczy zawodowych. Wykazały one przede wszystkim, że tłumacze za kluczową, a zarazem najważniejszą dla sukcesu zawodowego uznali kompetencję językową, a dopiero potem międzykulturową. Respondenci podkreślili także znaczenie czynników psychologicznych i afektywnych, które w omawianym modelu EMT uległy marginalizacji.

Przedmiotem zainteresowania Dariusza Hanusiaka jest sporządzanie notatek w tłumaczeniu ustnym konsekutywnym, w kombinacji językowej: polski-angielski-szwedzki. Badacz odniósł swoje rozważania do określonych cech, które posiadają wyżej wymienione języki. W artykule znajdziemy zalecenia dotyczące sposobu wyboru języka notatek, informacje o pozytywnych i negatywnych konsekwencjach podjętej decyzji, a także dydaktyczne zastosowania poczynionych obserwacji.

Kolejny wątek $w$ omawianej publikacji to kompetencje tłumacza z perspektywy dydaktycznej. Artykułów o bezpośrednio takiej tematyce znajdziemy $\mathrm{w}$ książce trzy. W pierwszym, zatytułowanym Kompetencja $w$ zakresie świadczenia usług tłumaczeniowych a uczenie się przez projekt, Łu- 
cja Biel poddała analizie metodę dydaktyczną uczenia się przez projekt, a także omówiła jej rolę w rozwoju kompetencji, zwłaszcza pod kątem świadczenia usług tłumaczeniowych (modelu EMT). Drugi artykuł dotyczy efektywności pracy zespołowej w dydaktyce przekładu. Jego autorka, Agata Sadza, dokonała krytycznej analizy semestralnego kursu "Zarządzanie projektem tłumaczeniowym”. Badaczka postawiła tezę, że praca $\mathrm{w}$ zespole powinna stać się ważnym aspektem w kształceniu kompetentnych tłumaczy, przedstawiła skuteczność zastosowanej metody i zamieściła implikacje wyników dla dydaktyki przekładu. Tematem trzeciego artykułu jest opracowywanie programów nauczania przeznaczonych do szkolenia tłumaczy. Sergiy Tyupa opisał model DACUM, służący przygotowywaniu tego typu programów i stosowany na ogromną skalę w szkołach zawodowych i organizacjach, zarówno prywatnych, jak i publicznych. Autor zaproponował, by model ten spróbować zastosować przy układaniu programów kształcenia tłumaczy ustnych i pisemnych.

Interesującym ujęciem kompetencji tłumacza, niejako z historycznego punktu widzenia, jest praca Anny Bednarczyk. Swoje obserwacja autorka oparła głównie na sytuacji tłumacza pochodzącego z obszaru rosyjskojęzycznego. Na szczególną uwagę zasługuje też artykuł Wojciecha Kubińskiego podejmujący problem etycznych uwarunkowań przekładu. Z kolei Agnieszka Gicala podeszła do tematu z perspektywy kognitywistycznej, podkreślając, że kompetencje tłumacza wiążą się nie tylko z płaszczyzną językową, ale także mentalną.

Szczególnie ciekawy w kontekście dynamicznie rozwijającego się ruchu neohermeneutycznego w przekładzie jest artykuł Piotra Bukowskiego. Autor podjął się próby sprecyzowania, czym są tak zwane hermeneutyczne kompetencje tłumacza, i udowodnienia, że w centrum hermeneutycznej myśli przekładoznawczej stoi kompetentny tłumacz. Warto przywołać w tym miejscu słowa badacza: „(...) o tzw. kompetencji translatorycznej napisano już całkiem sporo, przede wszystkim w kontekście pragmatyki przekładu. Nie brakuje więc ciekawych konceptualizacji i syntez. Z drugiej strony należy zauważyć, iż badacze zajmujący się tym tematem bardzo rzadko odwołują się do myślenia hermeneutycznego" (125). Dlatego też autor, odnosząc się do poglądów przedstawicieli filozofii hermeneutycznej i ruchu neohermeneutycznego w teorii przekładu, opisał, czym powinien się kierować kompetentny interpretator tekstów. Uwagę badacza zwróciły także takie aspekty podejmowane w filo- 
zofii hermeneutycznej, jak: dialog, obcość, horyzont interpretacyjny, koło rozumienia czy przedwiedza.

Publikację wzbogacono o zamieszczone na końcu Katalog alfabetyczny kompetencji tłumacza, noty o autorach, streszczenia w języku angielskim oraz Tabula gratulatoria. Ogromna różnorodność tematyczna prac zaprezentowanych $\mathrm{w}$ recenzowanym tomie, a także bogactwo perspektyw, $\mathrm{z}$ jakich podjęto omawiany fenomen, sprawiają, że z lektury tej publikacji skorzystać mogą i teoretycy, i praktycy przekładu. Wypada nadmienić, że wszystkie materiały zamieszczone $\mathrm{w}$ książce przygotowano wzorcowo zarówno pod względem merytorycznym, jak i językowym. Staranna szata graficzna i doskonała praca redakcyjna niewątpliwie wpływają na przyjemność płynącą z lektury tej niezwykle wartościowej pozycji. Jestem przekonana, że publikacja ta wejdzie na trwałe do dorobku polskiej translatoryki i będzie stanowiła inspirację dla kolejnych pokoleń badaczy przekładu. 